\title{
Multi-Lobed Mesiodens with a Palatal Talon Cusp - A Rare Case Report
}

\author{
Nayaka Basavanthappa NAGAVENI ${ }^{1}$ \\ Kagathur Veerbadrappa UMASHANKARA ${ }^{2}$ \\ SREEDEVI ${ }^{3}$ \\ Bokka Praveen REDDY ${ }^{2}$ \\ Nayaka Basavanthappa RADHIKA ${ }^{4}$ \\ Tirumala Suryaprakash SATISHA ${ }^{5}$
}

\begin{abstract}
${ }^{1}$ Department of Pedodontics and Preventive Dentistry, College of Dental Sciences, Davangere, Karnataka, India
${ }^{2}$ Department of Oral and Maxillofacial Surgery, College of Dental Sciences, Davangere, Karnataka, India

${ }^{3}$ Department of Oral Medicine and Radiology, College of Dental Sciences, Davangere, Karnataka, India

${ }^{4}$ Orthodontist, Private Practice, Pune, Maharashtra, India

${ }^{5}$ Periodontics, Department of Dental Surgery, Armed Forces Medical College, Pune, Maharashtra, India
\end{abstract}

\begin{abstract}
Mesiodens is a midline supernumerary tooth commonly seen in the maxillary arch and the talon cusp is a rare dental developmental anomaly seen on the lingual surface of anterior teeth. This paper presents a rare clinical case of development of talon cusp in a mesiodens with multiple lobes, which interfered with both occlusion and appearance of an 11-year-old patient. During clinical interview, the patient reported difficulty on mastication. Clinical and radiographic examination revealed that a supernumerary tooth with completely formed root was causing an occlusal interference. The supernumerary tooth was diagnosed as multi-lobed mesiodens associated with a palatal talon cusp. The treatment plan consisted in the extraction of the supernumerary tooth followed by orthodontic treatment for diastema closure and tooth alignment.
\end{abstract}

Key Words: mesiodens, supernumerary tooth, talon cusp, palatal talon.

\section{INTRODUCTION}

The term 'mesiodens' refers to a supernumerary tooth occurring in the anterior maxilla located between the maxillary central incisors. This is the most frequently seen supernumerary tooth followed by maxillary lateral incisors and mandibular premolars (1). The prevalence of mesiodens ranges from 0.15 to $1 \%$ of the population, and they occur more frequently in men than in women with a ratio of 2:1 (2). Numerous theories have suggested possible etiological factors such as extra divisions of the proliferating dental lamina, palatal offshoot from continued activity of the dental lamina after the normal number of tooth buds has formed, dichotomy of the tooth bud, and proliferation of odontogenic cell rests $(1,2)$.

Talon cusp is an accessory cusp-like structure projecting from the lingual surface of primary or permanent anterior teeth, and extending half the distance from the cementoenamel junction to the incisal edge (3). It has a striking predilection for the maxilla over the mandible, and the majority of cases occur in maxillary anterior teeth (4). The occurrence of the talon cusp in a supernumerary tooth is an extremely rare phenomenon, with only 5 case reports until now (4-8). In all of them, talon cusp occurred in either conical or supplemental type of mesiodens. This paper presents a case of development of the talon cusp in a mesiodens with multiple lobes. To the best of our knowledge, this report seems to be the first one of talon cusp on a maxillary multi-lobed mesiodens.

\section{CASE REPORT}

An 11-year-old Indian boy presented with complaint of an unusual looking tooth. On intraoral examination an extra tooth (supernumerary tooth) was

Correspondence: Dr. N. B. Nagaveni, Department of Pedodontics and Preventive Dentistry College of Dental Sciences, Davangere, Karnataka, India. Tel: +91-96-7512-9388. e-mail: nagavenianurag@gmail.com 
noticed in the midline between the maxillary central incisors. Patient had normal complete permanent dentition with no other abnormalities. Family history was not relevant. There were no signs of any syndromes. History of orofacial trauma was also absent. The morphology of the tooth crown was found to be unusual as it had 3 lobes separated by non-carious developmental grooves. One of them was located labially and the other two were located lingually. On further examination, it was found that the extra tooth also had a palatal talon cusp (Fig. 1). As this tooth occupied the midline position, there was no place for the other teeth and hence the permanent right central incisor was displaced labially and lateral incisor was displaced palatally. The tooth was also interfering with the occlusion (Fig. 2). Radiographic examination showed a supernumerary tooth with completely formed root, and also a talon cusp that appeared as a V-shaped radiopaque structure superimposed over a normal crown (Fig. 3).

Based on both clinical and radiographic findings, the supernumerary tooth was diagnosed as multi-lobed mesiodens associated with a palatal talon cusp. Since patient expressed dissatisfaction with this tooth and as it was causing occlusal interference, extraction followed by orthodontic treatment for diastema closure and tooth alignment was planned. Unfortunately, the patient did not return for the treatment.

\section{DISCUSSION}

Talon cusp is an anomaly of the tooth shape that

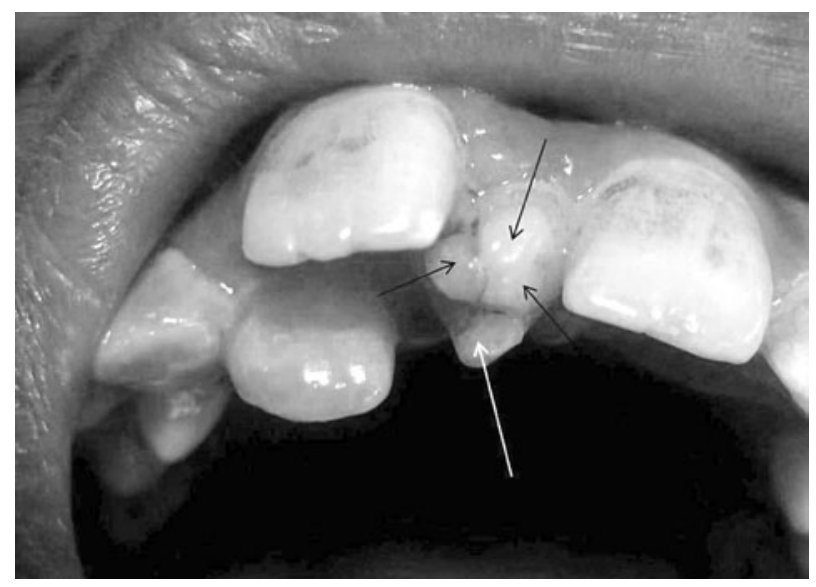

Figure 1. Mesiodens with 3 lobes (black arrows) and a palatal talon cusp (white arrow). arises during the morphodifferentiation stage of tooth development. It affects both genders either unilaterally or bilaterally. It has been reported that the anomalous cusp has a multifactorial etiology combining both genetic and environmental factors (8-10). Salama et al. (5) have reported that talon cusp may occur due to hyperactivity of the dental lamina and hence a supernumerary tooth can be expected. This anomaly appears to be more prevalent in patients with Mohr (11), Rubinstein-Taybi (12), and Sturge-Weber (13) syndromes. There are reports of the co-occurrence of the talon cusp with other dental anomalies like dens invaginatus, impacted mesiodens and complex odontome $(3,14,15)$. However, talon cusp occurring in a multi-lobed mesiodens has not been reported so far.

Mesiodens in the primary dentition are usually normal or conical in shape. In the permanent dentition, they show great variation of forms. Primosh (16) classified them into supplemental and rudimentary, according to its shape. Supplemental or eumorphic refers to supernumerary teeth of normal size and shape, and may also be termed incisiform. Rudimentary or dysmorphic defines teeth of abnormal shape and smaller size, including conical, tuberculate and molariform types. A conical mesiodens is small, peg-shaped (coniform) teeth with normal root; a tuberculate mesiodens is short, barrel shaped with normal appearing crown, or invaginated, but having rudimentary, incompletely developed root (16). In the present case, the crown of the mesiodens had 3 separate well-developed lobes resulting in an unusual crown morphology and completely formed root. Thus,

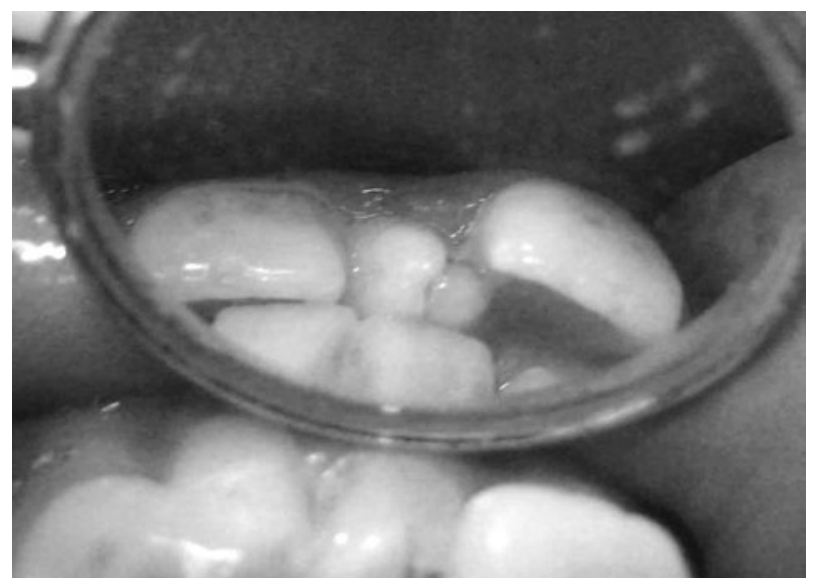

Figure 2. Image of the same mesiodens causing occlusal interference. 
the referred shapes were excluded and a diagnosis of multi-lobed mesiodens was made. Koch et al. (17) have classified mesiodens as $56 \%$ conical, $12 \%$ tuberculate, $11 \%$ supplemental, and $12 \%$ other configurations. Therefore, the present case report can be included in the 'other configuration' category of mesiodens.

It has been suggested that in $92 \%$ of the cases the talon cusp was found in the maxillary anterior region, with lateral incisors being the most commonly affected teeth, followed by central incisors and canines. Talon cusp of supernumerary teeth in the permanent dentition is extremely rare and has been reported only by two authors $(5,6)$. A rare occurrence of both facial and palatal talon cusp in a supernumerary primary tooth has been reported recently (7). Siraci et al. (8) reported a supernumerary primary tooth with facial and palatal talons with pulp extensions detected by micro-computed tomography. However, to date, no case of talon cusp on a mesiodens with abnormal shape i.e., having multiple lobes, has been reported in the literature.

Both talon cusp and mesiodens are considered the most common dental anomalies affecting the permanent dentition. Mesiodens may lead to several local problems such as diastema, displacement or rotation of adjacent teeth, development of dentigerous cyst, compromised esthetics, resorption of neighboring roots, crowding, and dilacerations of permanent teeth $(1,16,17)$. Clinical problems that may arise because of a talon cusp include occlusal interference, esthetic impairment,

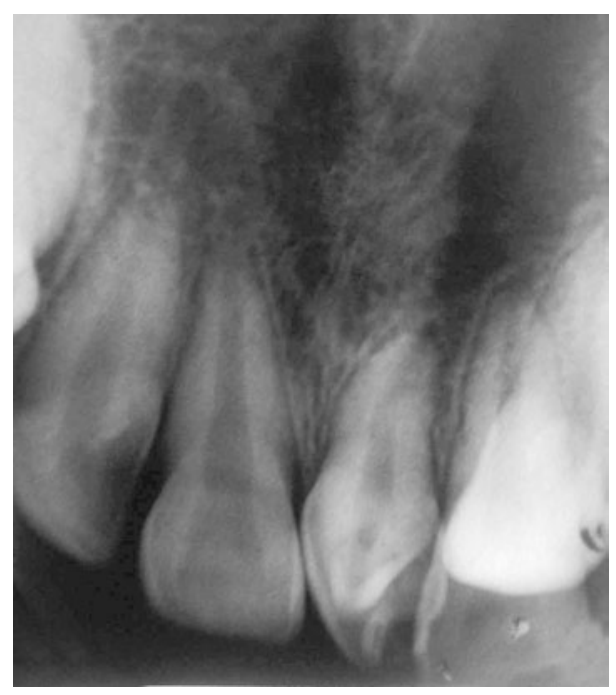

Figure 3. Periapical radiograph showing mesiodens associated with a talon. carious developmental grooves, displacement of teeth, periodontal problems, irritation of the tongue and diagnostic problems $(9,10)$. Therefore, the presence of both anomalies in young patients is of great concern, and early diagnosis is crucial to minimize these complaints.

The management of talon cusp varies with the circumstances of each case, and should be as conservative as possible. The treatment strategies are gradual abrasion with concomitant topical fluoride application as desensitizing agent (18), single appointment reduction with or without pulp therapy and sealant application in the developmental grooves (4). In the present case, as the talon cusp occurred accompanying a mesiodens, treatment for the talon was not required. The best treatment for the erupted mesiodens is extraction (19). Munns (19) suggested that the earlier the offending supernumerary tooth is removed, the better the prognosis. However, recently Rani et al. (20) have reported endodontic and esthetic management of maxillary lateral incisor fused to a supernumerary tooth associated with a talon cusp, which was diagnosed by spiral computed tomography.

In the present case, as mesiodens had created several problems to the patient namely occlusal interference, displacement of adjacent teeth and impaired esthetics, extraction of this tooth followed by orthodontic treatment for closure of the diastema and alignment of teeth was planned.

\section{RESUMO}

Mesiodens é um dente supranumerário mais comumente visto no arco maxilar na linha média, e a cúspide em garra (talon cusp) é uma anomalia dental de desenvolvimento rara que ocorre na face lingual de dentes anteriores. Este artigo apresenta um caso clínico raro de desenvolvimento de uma cúspide em garra em um mesiodens multilobulado que causava interferência tanto na oclusão quanto na aparência de um paciente de 11 anos de idade. Durante a entrevista clínica, o paciente relatou dificuldade na mastigação. Exame clínico e radiográfico revelou que um dente supranumerário com raiz completamente formada estava causando interferência oclusal. O dente supranumerário foi diagnosticado como sendo um mesiodens multilobulado associado a uma cúspide em garra palatina. O plano tratamento consistiu na extração do dente supranumerário seguida de tratamento ortodôntico para fechamento de diastema e alinhamento dos dentes.

\section{REFERENCES}

1. Hattab FN, Yassin OM, Rawashdeh MA. Supernumerary teeth: report of three cases and review of the literature. J Dent Child 1994;61:382-394.

2. Shafer WG, Hine MK, Levy BM. Developmental disturbances of 
oral and paraoral structures. In: A text book of oral pathology. $4^{\text {th }}$ ed. Philadelphia: WB Saunders; 1983. p. 47-49.

3. Davis PJ, Brook AJ. The professional of talon cusp; diagnosis, clinical features, associations and possible etiology. Br Dent $\mathrm{J}$ 1985;159:84-85.

4. Hattab FN, Yassin OM, al-Nimri KS. Talon cusp in permanent dentition associated with other dental anomalies: a review of literature and reports of seven cases. J Dent Child 1996;57:147149.

5. Salama FS, Hanes CM, Hanes PJ, Ready MA. Talon cusp: a review and two case reports on supernumerary primary and permanent teeth. J Dent Child 1990;57:147-149.

6. Nadkarni UM, Munshi A, Damle SG. Unusual presentation of talon cusp: two case reports. Int J Pediatr Dent 2002;12:332-335.

7 Topaloglu AK A, Eden E, Ertugrul F, Sutekin E. Supernumerary primary tooth with facial and palatal talon cusps: A case report. J Dent Child 2008;75:309-312.

8. Siraci E, Gungor HC, Taner B, Cehreli ZC. Buccal and palatal talon cusps with pulp extensions on a supernumerary primary tooth. Dentomaxillofac Radiol 2006;35:469-472.

9. Gunduz K, Acikgoz A. An unusual case of talon cusp on a geminated tooth. Braz Dent J 2006;17:343-346.

10. Peker I, Kaya E, Darendeliler-Yaman S. Clinic and radiographical evaluation of non-syndromic hypodontia and hyperdontia in permanent dentition. Med Oral Patol Oral Cir Bucal 2009;14:e393397.
11. Goldstein E, Mendina JL. Mohr syndrome or oral facial digital II report of two cases. J Am Dent Assoc 1974;89:377-382.

12. Gardner DG, Girgis SS. Talon cusp: a dental anomaly in the Rubinstein-Taybi syndrome. Oral Surg 1979;47:519-521.

13. Chen RJ, Chen HS. Talon cusp in primary dentition. Oral Surg Oral Med Oral Radiol Endod 1986;62:67-72.

14. Natkin E, Pitts DL, Worthington P. A case of talon cusp associated with other dental abnormalities. J Endod 1983;9:491-495.

15. Mader CL. Mandibular talon cusp. J Am Dent Assoc 1981;103:244246.

16. Primosch RE. Anterior supernumerary teeth. Assessment and surgical intervention in children. Pediatr Dent 1981;3:204-215.

17. Koch H, Schwartz O, Klausen B. Indications for surgical removal of supernumerary teeth in the premaxilla. Int J Maxillofacial Surg 1986;15:273-281.

18. Hattab FN, Wei SHY, Chan DCN. A scanning electronic microscopic study of enamel surfaces treated with topical fluoride agents in vivo. J Dent Child 1988;55:205-209.

19. Munns D. Unerupted incisors. Br J Orthod 1981;8:39-42.

20. Rani AK, Metgud S, Yakub SS, Pai U, Toshniwal NG, Bawaskar N. Endodontic and esthetic management of maxillary lateral incisor fused to a supernumerary tooth associated with a talon cusp by using spiral computed tomography as a diagnostic aid: a case report. J Endod 2010;36:345-349. 